\title{
PENGGUNAAN METODE CIRC PADA KEMAMPUAN MEMBACA PEMAHAMAN SISWA
}

\author{
Aprilentina*, Fahrurrozi, Miftahulkhairah Anwar, Jatu Wahyu Wicaksono \\ Program Studi Pendidikan Dasar Pascasarjana Universitas Negeri Jakarta \\ *Email:aprilentina 7526167231@,mhs.unj.ac.id
}

\begin{tabular}{ll}
\hline Informasi Artikel & Abstrak \\
\hline Kata kunci: & Pada kenyataannya kemampuan membaca pemahaman siswa masih \\
Membaca Pemahaman, & rendah karena siswa merasa cepat bosan dalam proses belajar. Makalah ini \\
Metode CIRC. & memaparkan hasil penggunaan metode CIRC pada kemampuan membaca \\
Metode kualitatif & pemahaman siswa. Metode ini digunakan untuk meningkatkan \\
& kemampuan membaca pemahaman siswa. Penelitian ini menggunakan \\
Diterima: 10-10-2020 & pendekatan kualitatif yang diperoleh melalui studi literatur. Menurut \\
Disetujui: 24-10-2020 & beberapa literatur dan penelitian yang dilakukan mengenai penggunaan \\
Dipubikasikan: 26-10-2020 & metode CIRC, terjadi peningkatan kemampuan membaca pemahaman \\
& siswa. Penggunaan metode CIRC dapat dikatakan sangat berhasil dalam \\
& meningkatkan kemampuan membaca pemahaman siswa.
\end{tabular}

\section{PENDAHULUAN}

Pendidikan pada dasarnya adalah usaha sadar untuk menumbuhkembangkan potensi sumber daya manusia peserta didik dengan cara mendorong dan memfasilitasi kegiatan belajar mereka. Pendidikan merupakan tanggung jawab bersama orang tua, pemerintah dan masyarakat. Sekolah dasar sebagai pendidikan formal yang pertama bagi anak merupakan sarana yang paling tepat dalam membentuk konsep berpikir anak. Peranan guru merupakan unsur yang dominan dalam menentukan pencapaian tujuan pembelajaran yang telah ditetapkan dalam kurikulum sekolah dasar. Bahasa Indonesia merupakan Bahasa yang mempunyai peran penting di dalam komunikasi baik secara lisan maupun tulisan, karena Bahasa Indonesia sebagai bahasa nasional kita. Pendidikan Bahasa Indonesia sebaiknya difokuskan pada empat keterampilan berbahasa. Dalam kurikulum di sekolah biasanya mencakup empat segi yaitu keterampilan menyimak (listening skills), berbicara (speaking skills), membaca (reading skills) dan menulis (writing skills). Kemampuan membaca merupakan keterampilan dasar bagi siswa, yang harus dikuasai agar mereka dapat mengikuti seluruh proses pembelajaran. Kemampuan membaca sangat penting bagi siswa karena banyak 
kegiatan belajar adalah membaca. Pembelajaran Bahasa Indonesia di SD saat ini masih bersifat satu arah atau berpusat kepada guru dan siswa masih terlalu pasif, sehingga merasa cepat bosan dalam proses belajar. Hal itu disebabkan karena guru masih belum dapat menggunakan metode pembelajaran dengan baik dan kurang bervariasi dalam proses mengajar. Guru dalam menyampaikan materi biasanya hanya menggunakan metode pembelajaran yang konvensional yang biasa disebut ceramah. Salah satu model pembelajaran yang dapat digunakan guru dalam mengajar adalah model pembelajaran kooperatif. Model pembelajaran kooperatif dapat digunakan secara efektif pada semua tingkat kelas dan semua mata pelajaran. Dengan pembelajaran kooperatif, interaksi yang terjadi di dalam kelompok dapat melatih siswa untuk menerima dan menghargai pendapat dari teman. Ada banyak pembelajaran cooperative learning, salah satu model pembelajaran kooperatif yang dapat digunakan dalam mengajarkan pembelajaran membaca adalah tipe Cooperative Integrated Reading and Composition (CIRC). Dalam CIRC siswa dituntut untuk menguasai pikiran utama dari suatu wacana dan kemampuan membaca dan menulis lainnya secara bersama-sama. Siswa dibagi kelompok oleh guru, kemudian menyelesaikan masalah yang terdapat pada bacaan tersebut secara bersama-sama. Dalam pembelajaran membaca pemahaman, guru dapat menggunakan metode pembelajaran CIRC. Tujuan utama menggunakan metode CIRC dalam pembelajaran adalah membantu siswa meningkatkan kemampuan membaca pemahaman dan meningkatkan hasil belajar siswa yang rendah. Dengan menggunakan metode tipe CIRC siswa dapat latihan membaca atau saling membaca, dituntut untuk menguasai pikiran utama dari suatu wacana dan kemampuan membaca serta menulis lainnya secara bersama-sama. Siswa dibagi kelompok oleh guru, kemudian menyelesaikan masalah yang terdapat dari bacaan tersebut secara bersama-sama.

\section{METODE}

Desain penelitian ini menggunakan pendekatan kualitatif. Pendekatan kualitatif desainnya bersifat umum, dan berubah-ubah atau berkembang sesuai dengan situasi di lapangan. Sebagaimana yang dijelaskan oleh Sugiono bahwa metode ini disebut juga dengan metode interpretatif karena data hasil penelitian lebih berkenaan dengan interpretasi terhadap data yang ditemukan di lapangan (Sugiyono, 2013). Selanjutnya Putra dan Lisnawati menyebutkan desain penelitian kualitatif biasanya bersifat global tidak terperinci, tidak pasti dan sangat fleksibel (Nusa \& Lisnawati, 2012). Dengan demikian desain hanya digunakan sebagai asumsi untuk melakukan penelitian oleh karena itu desain pada penelitian kualitatif bersifat fleksibel dan terbuka.

Arikunto menerangkan bahwa metode penelitian adalah cara yang digunakan oleh peneliti dalam mengumpulkan data penelitiannya (Arikunto, 2002) sedangkan Alwasilah mengungkapkan bahwa metode penelitian merupakan alat atau cara untuk menjawab pertanyaan penelitian (Alwasilah, 2009). Dengan demikian metode penelitian merupakan cara atau alat yang digunakan oleh peneliti untuk menjawab serangkaian pertanyaan yang dirumuskan dalam rumusan masalah. 
Selanjutnya metode penelitian yang digunakan dalam penulisan tesis adalah studi literatur, yaitu dengan cara meneliti dan memahami buku-buku, dokumen atau sumber tertulis lainnya yang relevan dan mendukung peningkatan kemampuan membaca pemahaman dengan metode CIRC.

Selain dari itu peneliti juga mengumpulkan dokumen-dokumen yang berkaitan dengan peningkatan kemampuan membaca pemahaman dengan metode CIRC. Arikunto menjelaskan dokumentasi berasal dari kata dokumen yang artinya barang-barang tertulis (Arikunto, 2002). Kemudian Sukardi menjelaskan mengenai macam-macam dokumen atau sumber literatur diantaranya adalah jurnal, laporan hasil penelitian, majalah ilmiah, surat kabar, buku yang relevan, hasil-hasil seminar, artikel ilmiah yang belum dipublikasi, narasumber, surat-surat keputusan dan sebagainya (Sukardi, 2009).

Penelitian kualitatif pada dasarnya merupakan suatu proses penyelidikan yang mirip dengan pekerjaan detektif. Dari sebuah penyelidikan yang mirip akan dihimpun data-data utama dan sekaligus tambahannya. Dalam teknik pengumpulan data Sugiyono menjelaskan bahwa teknik pengumpulan dilakukan dalam berbagai setting, berbagai sumber dan berbagai cara (Sugiyono, 2014).

Penelitian ini termasuk ke dalam penelitian studi kepustakaan. Oleh karena itu peneliti melakukan proses pengumpulan data berupa jurnal dan artikel, peneliti mengumpulkan beberapa jurnal internasional dan nasional, sedangkan setting tempat teknik pengumpulan data yang digunakan peneliti dalam penelitian ini adalah studi kepustakaan, yaitu dengan cara mencari data yang berkaitan dengan pembahasan.

Setelah melakukan proses pengumpulan data maka peneliti melakukan tahapan selanjutnya yaitu analisis data. Dikarenakan banyaknya data yang terkumpul, peneliti mengambil beberapa tahapan dalam menganalisis sebagai berikut:

1. Reduksi Data

Tahapan pertama peneliti menggunakan cara melalui reduksi data. Analisis data dengan cara mereduksi data merupakan proses mengorganisasikan data. Afifuddin dan Sabeni menjelaskan data diorganisasikan ke dalam satuan pola, kategori, dan satuan uraian dasar (Afifuddin \& Saebani, 2009). Proses kategorisasi ini melalui pengkodean data atau coding. Teknik coding atau pengkodean data dimaksudkan untuk mempermudah peneliti dalam menganalisis hasil temuan.

\section{Display Data}

Setelah melakukan reduksi data, maka langkah selanjutnya yang peneliti lakukan adalah menampilkan data atau display data. Dengan menampilkan data, maka akan mempermudah peneliti dalam memahami hasil penelitian.

\section{Content Analysis}

Adapun metode analisis data peneliti menggunakan analisis isi (content analysis). Afifuddin dan Sabeni menjelaskan analisis isi (content analysis) adalah penelitian yang bersifat pembahasan mendalam terhadap isi suatu informasi tertulis atau tercetak dalam media massa (Afifuddin \& Saebani, 2009). Metode analisis 
isi dalam penelitian ini digunakan untuk mengungkap keberhasilan metode CIRC dalam meningkatkan kemampuan membaca pemahaman. Analisis isi dapat diberlakukan pada semua penelitian sosial. Analisis isi dapat dipergunakan jika memiliki syarat berikut.

a. Data yang tersedia sebagian besar terdiri dari bahan-bahan yang terdokumentasi (buku, surat kabar, pita rekaman, naskah/manuscript).

b. Ada keterangan pelengkap atau kerangka teori tertentu yang menerangkan metode pendekatan terhadap data tersebut.

c. Peneliti memiliki kemampuan teknis untuk mengolah bahan-bahan atau data-data yang dikumpulkannya karena sebagian dokumentasi tersebut bersifat sangat khas atau spesifik.

Dengan demikian peneliti dalam metode ini menganalisa berdasarkan kajian tekstual yang ada dalam literatur tentang peningkatan kemampuan membaca pemahaman dengan metode CIRC. Setelah mendapatkan hasil analisis langkah terakhir adalah penarikan kesimpulan.

\section{HASIL DAN PEMBAHASAN}

Berdasarkan pencarian literatur, hasil penelitian terdahulu tentang penggunaan metode CIRC berfungsi untuk mendapatkan gambaran hasil penelitian. Partisipan dalam penelitian-penelitian di bawah mulai dari jenjang sekolah dasar hingga perguruan tinggi. Berikut artikel yang digunakan sebagai sampel penelitian pada kajian studi literatur.

Tabel 1. Pemetaan Literatur Artikel Ilmiah Metode CIRC

\begin{tabular}{|c|c|c|c|c|c|c|}
\hline \multirow[t]{2}{*}{ No. } & \multirow[t]{2}{*}{ Studi } & \multirow[t]{2}{*}{ Tipe Penelitian } & \multirow[t]{2}{*}{ Hasil Penelitian } & \multicolumn{3}{|c|}{ Karakteristik Partisipan } \\
\hline & & & & Pendidikan & Usia & Total $(\mathrm{n})$ \\
\hline 1. & $\begin{array}{l}\text { Madhu Gupta and Jyoti } \\
\text { Ahuja (2014) }\end{array}$ & Kuantitatif & Meningkat & SMP & $9-15$ & 140 \\
\hline 2. & $\begin{array}{l}\text { David W. Johnson, } \\
\text { Roger T. Johnson, and } \\
\text { Mary Beth Stanne (2000) }\end{array}$ & Kuantitatif & Meningkat & $\mathrm{SD}-\mathrm{PT}$ & $7-22$ & 158 \\
\hline 3. & $\begin{array}{l}\text { Mohammad Amin } \\
\text { Karafkan and Zahra } \\
\text { Aghazadeh (2015) }\end{array}$ & Kuantitatif & Meningkat & SMA & $16-18$ & 207 \\
\hline 4. & $\begin{array}{l}\text { Zahra Kamdideh, Reza } \\
\text { Vaseghi and Saeedeh } \\
\text { Talatifard (2019) }\end{array}$ & Kuantitatif & $\begin{array}{l}\text { RTR lebih efektif } \\
\text { dibanding CIRC }\end{array}$ & PT & $18-23$ & 53 \\
\hline 5. & $\begin{array}{l}\text { Dina Rahma Br Ginting } \\
\text { (2017) }\end{array}$ & $\begin{array}{l}\text { Kualitatif - } \\
\text { Kuantitatif }\end{array}$ & Meningkat & SMP & $14-15$ & 41 \\
\hline 6. & $\begin{array}{l}\text { Endang Sulistianingsih } \\
\text { (2018) }\end{array}$ & $\begin{array}{l}\text { Kuantitatif - } \\
\text { Kualitatif }\end{array}$ & Meningkat & PT & $19-20$ & 18 \\
\hline 7. & $\begin{array}{l}\text { Slavin, Nancy, Anna and } \\
\text { Robert (1995) }\end{array}$ & Kualitatif & Meningkat & $\mathrm{SD}$ & $9-10$ & - \\
\hline 8. & $\begin{array}{l}\text { Wilkinson Daniel Wong } \\
\text { Gonzales and Patrisha } \\
\text { Lliane Torres (2015) }\end{array}$ & Kuantitatif & Meningkat & SMP & $14-15$ & 127 \\
\hline 9. & Behice Varışoğlu (2016) & $\begin{array}{l}\text { Kuantitatif - } \\
\text { Kualitatif }\end{array}$ & Meningkat & PT & $21-35$ & 16 \\
\hline
\end{tabular}




\begin{tabular}{|c|c|c|c|c|c|c|}
\hline 10. & $\begin{array}{l}\text { Nadine Spo"rer, Joachim } \\
\text { C. Brunstein and Ulf } \\
\text { Kieschke (2008) }\end{array}$ & Kuantitatif & Meningkat & SD & $9-12$ & 210 \\
\hline 11. & Tira Nur Fitria (2015) & $\begin{array}{l}\text { Kuantitatif - } \\
\text { Kualitatif }\end{array}$ & Meningkat & SMP & $14-15$ & - \\
\hline 12. & $\begin{array}{l}\text { Martono Martono, Eva } \\
\text { Purwanti, M. Syukri, } \\
\text { Soeharto Soeharto and } \\
\text { Muh Barid Nizarudin } \\
\text { Wajdi (2019) }\end{array}$ & $\begin{array}{l}\text { Kuantitatif - } \\
\text { Kualitatif }\end{array}$ & Meningkat & SMP & $13-14$ & 31 \\
\hline 13. & $\begin{array}{l}\text { Andri Donal and Batdal } \\
\text { Niati (2018) }\end{array}$ & Kuantitatif & $\begin{array}{c}\text { CIRC lebih efektif } \\
\text { dibanding kelompok } \\
\text { kecil }\end{array}$ & PT & $21-22$ & 39 \\
\hline 14. & $\begin{array}{l}\text { Amelia Tankersley and } \\
\text { Joshua A. Cuevas (2019) }\end{array}$ & Kualitatif & Meningkat & $\mathrm{SD}$ & $8-9$ & 60 \\
\hline 15. & $\begin{array}{l}\text { Robert, Nancy, Slavin, } \\
\text { Anna (1987) }\end{array}$ & $\begin{array}{l}\text { Kualitatif - } \\
\text { Kuantitatif }\end{array}$ & Meningkat & SD & $9-10$ & 911 \\
\hline 16. & $\begin{array}{l}\text { Sarojani S. Mohammed, } \\
\text { Elizabeth Swanson, Greg } \\
\text { Roberts, Sharon Vaughn, } \\
\text { Janette K. Klingner and } \\
\text { Alison Gould Boardman } \\
(2010)\end{array}$ & $\begin{array}{l}\text { Kualitatif - } \\
\text { Kuantitatif }\end{array}$ & Meningkat & SMP & $13-14$ & 61 \\
\hline 17. & $\begin{array}{l}\text { L.C. Rosa Dewi, IB. } \\
\text { Putrayasa, IA. Md } \\
\text { Darmayanti (2017) }\end{array}$ & $\begin{array}{l}\text { Kuantitatif - } \\
\text { Kualitatif }\end{array}$ & Meningkat & SMP & $14-15$ & 38 \\
\hline 18. & $\begin{array}{l}\text { Pradistya Arifah Dwiarno } \\
(2017)\end{array}$ & $\begin{array}{l}\text { Kualitatif - } \\
\text { Kuantitatif }\end{array}$ & Meningkat & $\mathrm{SD}$ & $9-10$ & 51 \\
\hline 19. & $\begin{array}{l}\text { Naeklan Simbolon dan } \\
\text { Chintia Khoiri (2016) }\end{array}$ & $\begin{array}{l}\text { Kualitatif - } \\
\text { Kuantitatif }\end{array}$ & Meningkat & $\mathrm{SD}$ & $11-12$ & 27 \\
\hline 20. & $\begin{array}{l}\text { Winda Oktafiani, } \\
\text { Irdamurni dan Damri } \\
(2018)\end{array}$ & Kuantitatif & Meningkat & $\mathrm{SD}$ & $10-11$ & 5 \\
\hline 21. & $\begin{array}{l}\text { Yulia Rahmi dan Ilham } \\
\text { Marnola (2020) }\end{array}$ & Kualitatif & Meningkat & $\mathrm{SD}$ & $11-12$ & 20 \\
\hline 22. & Sutirto (2016) & $\begin{array}{l}\text { Kuantitatif - } \\
\text { Kualitatif }\end{array}$ & Meningkat & SD & $9-10$ & 29 \\
\hline 23. & $\begin{array}{l}\text { Yunita Ningrum dan } \\
\text { Firosalia Kristin (2019) }\end{array}$ & $\begin{array}{l}\text { Kuantitatif - } \\
\text { Kualitatif }\end{array}$ & Meningkat & SD & $10-11$ & 26 \\
\hline 24. & $\begin{array}{l}\text { Vina Anggia Nastitie } \\
\text { Ariawan, Niken Tri } \\
\text { Utami dan Rahman } \\
(2018)\end{array}$ & Kualitatif & Meningkat & $\mathrm{SD}$ & $11-12$ & 20 \\
\hline 25. & $\begin{array}{l}\text { Intan Nurhidayah, Effy } \\
\text { Mulyasari dan Babang } \\
\text { Robandi (2017) }\end{array}$ & $\begin{array}{l}\text { Kualitatif - } \\
\text { Kuantitatif }\end{array}$ & Meningkat & SD & $11-12$ & 27 \\
\hline 26. & $\begin{array}{l}\text { Ni Kadek Sudiarni dan } \\
\text { Made Sumantri (2019) }\end{array}$ & Kuantitatif & Meningkat & $\mathrm{SD}$ & $11-12$ & 67 \\
\hline 27. & $\begin{array}{l}\text { Fatimatu Zahrah } \\
\text { Abdurahman dan } \\
\text { C.Indah Nartani (2017) }\end{array}$ & $\begin{array}{l}\text { Kuantitatif - } \\
\text { Kualitatif }\end{array}$ & Meningkat & $\mathrm{SD}$ & $11-12$ & 18 \\
\hline
\end{tabular}




\begin{tabular}{|c|c|c|c|c|c|c|}
\hline 28. & Budi Febriyanto (2016) & Kuantitatif & $\begin{array}{c}\text { CIRC lebih efektif } \\
\text { dibanding } \\
\text { konvensional }\end{array}$ & SD & $11-12$ & 60 \\
\hline 29. & $\begin{array}{l}\text { Winda Sri Gusviani } \\
\text { (2019) }\end{array}$ & Kualitatif & Meningkat & SD & $10-11$ & 22 \\
\hline 30. & $\begin{array}{l}\text { Devi Aviani Safitri dan } \\
\text { Siti Ngaisah (2018) }\end{array}$ & Kuantitatif & Meningkat & SD & $11-12$ & 55 \\
\hline
\end{tabular}

Kajian literatur tentang penggunaan metode CIRC dilakukan pada 30 artikel di atas. Berdasarkan hasil penelitian dari 30 artikel menunjukkan bahwa penggunaan metode CIRC dapat meningkatkan kemampuan membaca pemahaman siswa. Kemampuan membaca pemahaman siswa melalui metode CIRC meningkat dibandingkan dengan kemampuan membaca pemahaman siswa melalui metode lain. Tetapi, ada penelitian lain yang menjelaskan kemampuan membaca pemahaman siswa lebih mendapatkan peningkatan dengan strategi RTR (Reciprocal Teaching Reading) dibandingkan dengan kemampuan membaca pemahaman yang menggunakan metode CIRC.

Kajian literatur di atas merupakan hasil penelitian terdahulu yang berkaitan tentang peningkatan kemampuan membaca pemahaman melalui metode CIRC. Berdasarkan 29 artikel ilmiah di atas kemampuan membaca pemahaman dan metode CIRC, diperoleh hasil penelitian yang menjelaskan bahwa metode CIRC menjadikan proses pembelajaran efektif dan efisien sehingga kemampuan membaca pemahaman siswa meningkat. Metode CIRC (Cooperative Integrated Reading and Composition) sangat membantu dalam proses pembelajaran dan berdampak positif bagi siswa dan guru. Penggunaan metode CIRC dalam pembelajaran, khususnya dalam membaca pemahaman digunakan untuk mempermudah kemampuan membaca pemahaman siswa dalam memahami bacaan dengan saling bertukar pikiran atau pendapat dengan teman kelompoknya.

Berdasarkan hasil penelitian terdahulu dalam artikel yang telah dipaparkan di atas. Fatimatu menyimpulkan bahwa penggunaan metode CIRC (Cooperative Integrated Reading And Composition) dapat meningkatkan kemampuan membaca pemahaman siswa. Hasil tes pada siklus I menghasilkan nilai rata-rata kelas 74,2 dengan persentase ketuntasan klasikal 74\%, dan siklus II menghasilkan nilai rata-rata kelas 85,6 dengan persentase kelulusan klasikal 86\% (Abdurahman, n.d.). Winda menjelaskan bahwa penggunaan metode pembelajaran Cooperative Integrated Reading And Composition (CIRC) pada peningkatan kemampuan membaca pemahaman siswa ini sangat tepat diterapkan karena dalam metode pembelajaran Cooperative Integrated Reading And Composition (CIRC) dapat meningkatkan antusiasme siswa, keaktifan siswa, dan konsentrasi siswa (Gusviani, 2019).

Andri dan Batdal menemukan bahwa penggunaan metode CIRC mendapatkan nilai lebih baik dibanding dengan kelompok diskusi lainnya (Donal \& Niati, n.d.). Namun, Zahra, dkk menemukan bahwa strategi RTR (Reciprocal Teaching Reading) lebih memberikan efek signifikan dibandingkan dengan menggunakan metode CIRC (Kamdideh, 2019). 
Budi menjelaskan bahwa siswa yang memperoleh pembelajaran model CIRC memiliki peningkatan keterampilan membaca pemahaman yang lebih tinggi dibanding siswa yang memperoleh pembelajaran konvensional (Febriyanto, 2016).

Literatur Peningkatan Kemampuan Membaca Pemahaman Melalui Metode CIRC

Studi literatur tentang peningkatan kemampuan membaca pemahaman melalui metode CIRC terdapat 27 artikel penelitian. Adapun pembahasannya adalah sebagai berikut:

Yulia dan Ilham menemukan bahwa pembelajaran membaca pemahaman dengan menggunakan pendekatan kooperatif tipe CIRC dapat meningkatkan hasil belajar siswa. Penggunaan pendekatan kooperatif tipe CIRC dalam pembelajaran membaca pemahaman terbukti efektif dapat meningkatkan hasil belajar karena pembelajaran dilaksanakan sesuai dengan perancangan, pelaksanaan dan evaluasi (Rahmi \& Marnola, 2020).

Selanjutnya, Pradistya juga menemukan bahwa terjadi peningkatan kemampuan membaca pemahaman melalui teknik Cooperative Integrated Reading and Composition (CIRC) pada tahap prabaca, saatbaca, dan pascabaca. Namun keberhasilan meningkatnya kemampuan membaca pemahaman juga ditentukan oleh proses pembalajaran yang mendukung yang dilakukan oleh guru (Dwiarno, n.d.).

Sutirto menemukan bahwa penerapan metode CIRC dapat meningkatkan kemampuan siswa dalam memahami isi suatu bacaan. Keberhasilan tersebut dapat dilihat dari keaktifan siswa dalam pembelajaran yang meningkat dan telah mencapai kategori aktif. Penerapan metode CIRC dapat mendorong siswa lebih senang membaca.

Dina menemukan bahwa bahwa penerapan metode CIRC dapat meningkatkan kemampuan siswa dalam pemahaman membaca dan pembelajaran mengajar dapat menjadi efektif (Rahma \& Ginting, 2017). Dengan kata lain, kemampuan siswa menjadi lebih baik di pertemuan pertama hingga pertemuan terakhir dengan menggunakan metode CIRC.

Rosa, dkk menemukan bahwa ada peningkatan aktivitas guru dan siswa dalam membaca pemahaman teks diskusi dalam menerapkan model pembelajaran CIRC (Singaraja, Dewi, Putrayasa, \& Darmayanti, 2017). Model pembelajaran CIRC dapat dijadikan sebagai salah satu pilihan alternatif dalam upaya peningkatan kemampuan membaca pemahaman siswa.

Yunita dan Firosalia menemukan bahwa penerapan model Cooperative Intgrated Reading and Compotition (CIRC) dapat meningkatkan keterampilan membaca pemahaman (Penelitian et al., 2019). Penerapan model pembelajaran Cooperative Integrated Reading and Compotition dalam meningkatkan keterampilan membaca pemahaman menunjukkan perbandingan hasil yang signifikan pada setiap siklusnya.

Vina, dkk menemukan adanya peningkatan keterampilan membaca di setiap siklus dengan menerapkan model CIRC (Anggia et al., 2018). Merujuk pada temuan tersebut, maka disimpulkan bahwa penerapan model CIRC berbantuan media cetak dapat meningkatkan keterampilan membaca pemahaman siswa. 
Intan, dkk menemukan bahwa penerapan model kooperatif tipe CIRC dapat meningkatkan kemampuan membaca pemahaman siswa (Nurhidayah, Mulyasari, \& Robandi, n.d.). Hal tersebut dapat dilihat dari peningkatan hasil tes kemampuan membaca pemahaman dalam setiap aspek membaca pemahaman dalam persentase setiap siklusnya.

Kadek dan Made menemukan keterampilan membaca pemahaman kelompok siswa yang dibelajarkan dengan menggunakan metode pembelajaran Cooperative Integrated Reading and Composition (CIRC) berada pada kategori sangat baik (Sudiarni \& Sumantri, 2019). Terdapat perbedaan yang signifikan pada keterampilan membaca pemahaman siswa yang dibelajarkan dengan menggunakan model pembelajaran CIRC.

Devi dan Siti menemukan bahwa terdapat perbedaan kemampuan membaca pemahaman antara siswa yang mengikuti pembelajaran dengan metode CIRC dengan siswa yang mengikuti pembelajaran menggunakan model konvensional atau model pembelajaran langsung (Safitri \& Ngaisah, 2018). Hal ini menunjukkan bahwa pembelajaran dengan menerapkan metode CIRC mampu meningkatkan hasil kemampuan membaca pemahaman siswa, atau dapat dikatakan metode CIRC berpengaruh terhadap kemampuan membaca pemahaman siswa.

Berdasarkan kajian literatur yang telah dijelaskan di atas partisipan penelitian penggunaan metode CIRC pada kemampuan membaca pemahaman merupakan siswa mulai dari jenjang sekolah dasar hingga perguruan tinggi. Hasil analisis data pada studi literatur tentang penggunaan metode CIRC pada kemampuan membaca pemahaman siswa menunjukkan bahwa adanya peningkatan hasil kemampuan membaca pemahaman siswa menggunakan metode CIRC. Dari 30 jurnal relevan baik internasional dan nasional di atas didapat bahwa penggunaan metode CIRC berhasil meningkatkan kemampuan membaca pemahaman siswa mulai dari tingkat sekolah dasar hingga perguruan tinggi.

Penelitian kepustakaan adalah serangkaian penelitian yang berkenaan dengan metode pengumpulan data pustaka atau penelitian yang dilakukan di perpustakaan yang objek penelitiannya digali melalui beragam informasi kepustakaan (buku, ensiklopedi, jurnal ilmiah, koran, majalah, dan dokumen) (Sukmadinata, 2009). Kelebihan dari studi pustaka/literatur ini yaitu dapat memperoleh banyak sumber informasi tanpa memakan banyak biaya, memerlukan banyak waktu dan tenaga karena sumber (jurnal) sudah terkumpul jadi satu di dalam ruangan perpustakaan. Tetapi, di samping itu penelitian studi kepustakaan ini juga memiliki kekurangan yaitu dibutuhkan ketelitian dan kepandaian dalam mencari jurnal-jurnal yang relevan agar dapat dipergunakan sebagai sumber perolehan data dalam penelitian yang dilakukan.

Penggunaan metode CIRC ini memiliki kekuatan dan kelemahan dalam pelaksanaannya yaitu kekuatan dari metode ini yaitu seluruh kegiatan belajar lebih bermakna bagi siswa sehingga hasil belajar siswa akan dapat bertahan lebih lama (Liani Niliawati, Ruswandi Hermawan, 2018). Sedangkan kelemahan penggunaan metode CIRC ini tidak dapat berjalan dengan baik dalam situasi pandemi seperti ini dikarenakan metode CIRC terdiri dari tiga unsur penting: kegiatan-kegiatan dasar terkait, pengajaran langsung pelajaran 
memahami bacaan, dan seni berbahasa dan menulis terpadu (Slavin, 2008). Jadi, salah satu kelemahan dari penggunaan metode CIRC ini adalah harus dilaksanakan secara langsung di lapangan.

\section{KESIMPULAN}

Hasil kemampuan membaca pemahaman siswa menggunakan metode CIRC ini mengalami peningkatan. Peningkatan kemampuan membaca pemahaman siswa dengan metode CIRC perlu dikembangkan sebagai inovasi dalam pembelajaran pemahaman teks bacaan. Penggunaan metode CIRC pada kemampuan membaca pemahaman siswa memberikan visualisasi dan gambaran yang konkrit bagi guru untuk digunakan dalam kegiatan pembelajaran.

\section{DAFTAR PUSTAKA}

Abdurahman, F. Z. (n.d.). Peningkatan kemampuan membaca pemahaman isi cerita anak melalui penggunaan metode circ pada siswa kelas v sd negeri serangan. 273-277.

Anggia, V., Ariawan, N., Utami, N. T., Pendidikan, J., Sekolah, G., Dasar, J. P., \& Indonesia, U. P. (2018). Peningkatan keterampilan membaca pemahaman siswa sekolah dasar melalui implementasi model circ berbantuan media cetak. 1(2), 95-104.

Donal, A., \& Niati, B. (n.d.). The Effect of Cooperative Integrated Reading Composition (CIRC) on Students ' Reading Comprehension of Essay at English Study Program of University of Pasir Pengaraian. 978-979.

Dwiarno, P. A. (n.d.). Peningkatan Keterampilan Membaca Pemahaman pada Siswa Kelas III SDN Sumberbening 4 Kecamatan Bringin Kabupaten Ngawi Melalui Teknik CIRC. 42-53.

Febriyanto, B. (2016). Penerapan Model Cooperative Integrated Reading and Composition Dalam Pembelajaran Keterampilan Membaca Pemahaman. 2(2).

Gusviani, W. S. (2019). Upaya Meningkatkan Kemampuan Membaca Pemahaman... - Winda Sri Gusviani. 2(1), 10-22.

Kamdideh, Z. (2019). The Effects of Reciprocal Teaching of Reading' and 'Cooperative Integrated Reading and Composition' on the Reading Comprehension of Iranian EFL Intermediate Students. 9(9), 1111-1117.

Liani Niliawati, Ruswandi Hermawan, \& A. R. R. (2018). Penerapan Metode Circ (Cooperative Integrated Reading and Composition ) Untuk Meningkatkan Kemampuan Membaca Pemahaman Siswa Kelas Iv. Jurnal Pendidikan Guru Sekolah Dasar, III (I), 23-24.

Nurhidayah, I., Mulyasari, E., \& Robandi, B. (n.d.). PENERAPAN MODEL PEMBELAJARAN KOOPERATIF TIPE PEMAHAMAN.

Penelitian, J., Pendidikan, A., Ningrum, Y., Kristin, F., Guru, P., Dasar, S., Pemahaman, K. M. (2019). E d u k a si. 11(1), 43-54.

Rahma, D., \& Ginting, B. (2017). The Implementation of Cooperative Integrated Reading and Composition Strategy to Improve the Students' Ability in Reading Comprehension. 104(Aisteel), 113-117.

Rahmi, Y., \& Marnola, I. (2020). Jurnal basicedu. 4(3), 662-672. https://doi.org/10.31004/basicedu.v4i3.406

Safitri, D. A., \& Ngaisah, S. (2018). PENGARUH METODE CIRC (COOPERATIVE INTEGRATED READING AND COMPOSITION ) TERHADAP KEMAMPUAN MEMBACA PEMAHAMAN SISWA PADA MATERI CERITA. 10(1), 75-84.

Singaraja, S. M. P. N., Dewi, L. C. R., Putrayasa, I. B., \& Darmayanti, I. A. (2017). PENERAPAN MODEL COOPERATIVE INTEGRATED READING AND COMPOSITION ( CIRC) UNTUK MENINGKATKAN KEMAMPUAN MEMBACA PEMAHAMAN TEKS DISKUSI PADA 
SISWA KELAS VIII . 4. (2).

Sudiarni, N. K., \& Sumantri, M. (2019). PENGARUH MODEL PEMBELAJARAN CIRC BERBANTUAN MEMBACA PEMAHAMAN. 2(1), 71-81. 